TURIZAM

Volume 14 , Issue 1

$22-40$ (2010)

\title{
Examining Cultural Tourism Attractions for Foreign Visitors: The Case of Camel Wrestling in Selçuk (Ephesus)
}

\author{
Vedat Çalışkan*
}

Received: February 2010| Accepted: March 2010

\begin{abstract}
This study focuses on the Camel Wrestling Festival in Selçuk, which has gained importance with its tourist appeal among traditional camel wrestling organizations in Western Anatolia. The study aimed to investigate those aspects of the Festival, which were found to be attractive for foreign visitors, and to evaluate the impacts of tourism on this traditional event. The study data were obtained from the surveys that were completed by 56 foreign visitors at the Camel Wrestling Festival in Selçuk on January 18, 2009. Findings of the study demonstrate that this traditional event attracts foreign visitors from various countries worldwide, for they are curious about this event and desire to have a cultural-authentic experience. The Camel Wrestling Festival in Selçuk is a cultural heritage, which has not been commercialized or lost its authentic significance yet, although it is vulnerable to the impact of international tourism. Nevertheless, handing this value down to the future by conserving it with its cultural surroundings is possible through a sustainable tourism policy. The Camel Wrestling Festival in Selçuk is in the process of becoming a touristic product, and the proposals in the study contribute to the development of a policy for the festival concerned.
\end{abstract}

Keywords: camel wrestles, festivals, cultural heritage, Ephesus, Western Anatolia

\section{Introduction}

Today there are various events and festivals that utilize the unique abilities and features of some animals and that have a traditional dimension in various countries worldwide. The most commonly known example is the bull fights, which are associated with Spain and Mexico but different forms of which are also observed in countries such as Japan and Turkey (Shubert, 200I; Ishii, 2006; Türkoğlu, 1990). Camel-related events held in the world, however, are in the form of camel races and camel wrestles (Çalışkan, 2009). The events, where

* Onsekiz Mart University, Faculty of Siciences and Arts, Department of Geography, 17020, Çanakkale, Turkey. v.caliskan@comu.edu.tr 
Arabian camels running faster than Asian camels are raced, are held in various Arabian countries such as the United Arab Emirates and Qatar in particular (Khalaf, 2000; Nawata, 2003). Apart from Afghanistan and Pakistan, where camel wrestling matches are few and irregular, the most comprehensive and common camel wrestling matches are held in Turkey (Ibrahimi, 2007; Raza, 2008).

Tourism is a resource industry, dependent for its basic appeal upon nature's endowment and society's heritage. The natural appeal of a locality may rest upon one (or more) of its physical attributes: the climate, landforms, landscapes, flora or fauna; whilst socio-cultural heritage may draw tourists seeking to enjoy centres of learning or entertainment, to visit places of interest or historic significance or to view buildings or ruins of buildings. Sociocultural attractions may also extend to the perusal of artifacts or works of art; the experience of customs, rituals or performing arts; enjoyment of foreign cuisine; or festivals and spectacles (Williams, 2003:7I). Recently people have begun to be increasingly interested in the existing local cultures except for their own culture, besides seeing the traces of ancient civilizations or cultures (Emekli, 2006: 54). With the growth of the importance of traditionalized local events over time during this process, many events have gained the characteristics of a festival and evolved rapidly, become the attractions for visitors, targeted tourist markets (Smith and Forest, 2006:I4O,I48) and become an essential part of cultural tourism. Therefore, festivals are classified as a type of cultural and heritage tourism by many researchers (Tighe, I986; Esu, Arrey, 2009; Zeppel, Hall, I992; Timothy, Boyd, 2006).

The general pattern of tourism development in the developed world over the last 50 years or so intersects at numerous points with occasions of festivity, carnival and performance rituals across the world in general. Festivals, whether as "traditional" moments of social celebration or as constructed and highly orchestrated events, have been absorbed into the expansive stock of "products" that tourists desire (Picard, Robinson 2006:2). Truly, it seems that festivals, perhaps inevitably, engage in tourism processes. From a tourism perspective, festivals create 'product', enliven a destination, and promise a glimpse into the authentic culture of a place (Quinn, 2006:3OI). With a centuries-old history in the locality, its values, music, rituals and foodways, the Camel Wrestling Festival in Selçuk is a living culture in Western Anatolia. As a part of cultural heritage tourism, camel wrestling events are touristic resources attracting more and more visitors day by day.

The camel wrestling organizations in the form of a festival are cultural and tourism events that are unique to Turkey (Çulha, 2008; Çalışkan, 2009). The camel wrestles held in 87 settlements in Western Anatolia every year are important sources of entertainment for the local society in winter months. In Western Anatolia, wrestling organizations assume quite essential social, cultural and economic functions in their areas of distribution. During this event (held on Sundays at some specific time during the year), the residents in these surroundings meet, are entertained, become socialized, gain income, produce, and consume (Çalışkan, 2009:I24). Camel wrestles are about to gain a touristic function as well since they, as original and authentic experiences, attract foreign visitors. This process is also supported by the fact that many settlements, where camel wrestles are held, are simultaneously settlements that have become famous for tourism in Turkey. Among these settlements, Selçuk is particularly remarkable in that foreign visitors are interested in it and Selçuk Festival is the greatest organization. Held on the 3rd Sunday of January every year, "Camel Wrestling Festival in Selçuk" hosts around I5,OOO spectators. Besides the high number of spectators arriving to watch the contest of around Ioo high-quality wrestling camels, the festival is also important because around 500 foreign visitors express their interest in it every year. 
Wrestles are held between male camels of a special genus called 'Tülü'. They are male camels obtained by breeding the single-hump female Arabian camels of Dromedary species and double-hump Asian male camels of Bactrian Camel species (Camelus bactrianus) (Özbeyaz, 1997:48). A camel wrestle is an event where games based on animal power and ability are exhibited in front of a community of spectators. It is outstanding as it is called a wrestle rather than a fight. Despite the lack of written rules, wrestling rules are identical everywhere. These rules first cover some precautions in order to prevent camels from being injured and worn out. In time, the rules changed to reduce violence and prevent animals from being hurt. Camels are wrestled for IO minutes once a week. In the I980s, wrestles lasted 15 minutes. Today, because of this shortened period, most games end in a draw (Çalışkan, 2009:I24).

Camel wrestles are a part of the cultural heritage of Anatolia. Camel wrestles - which have a history that dates back to ancient times - and the cultural features with respect to camel wrestles are being sustained by means of festivals today. As it is known, the origin of Turks' interest in camels goes back to the depths of the culture they had created in Central Asia. In this culture, a male camel was particularly a cult and a totemic animal in the belief of pre-Islamic Turks (Öngel, 2OOI:378). Dede Qorqut Oghuznames, an important work for the history of Turkish culture, contained the story of Boğaç Khan. This story which contained a description that a bull and a buğra (a male camel) of Bayındır Khan were wrestled twice annually (once in summer and once in autumn) is important because it indicates the origin of camel wrestles (Tezcan, Boeschoten, 2006).

Today the distribution of camel wrestles within a specific area in Anatolia clearly displays their close relationship with culture (See Çalışkan, 2009). As a matter of fact, in the past, the nomadic Turks in this area were closely interested in camel dealing and camel raising. Furthermore, there are various traditional productions, commercial activities, spaces, rituals, clothes and finery, types of music, dances, eating and drinking activities and etc., which carry on existing in association with camel wrestles today. These rich elements and relationships create an almost special economic and cultural fabric that supports each other's existence. In this sense, beyond being traditional events, camel wrestles are a rich attraction for international tourism.

It is true that recently foreign visitors have been increasingly interested in camel wrestling festivals primarily in Selçuk and in settlements like Kuşadası. Foreign visitors are almost festival components at the Camel Wrestling Festival in Selçuk. Thus, the objectives of the study were to determine those aspects of traditional camel wrestling events, which attracted foreign visitors, and to find the reasons why tourists participated in the festival. In addition, it was aimed to make proposals to protect the authentic structure of the festival and the quality of tourist experience against negative impacts.

\section{Literature Review}

The impacts of festival tourism on events with a traditional aspect have been considerably documented in literature. There are studies on this matter which evaluate tourism's positive impacts in its various dimensions. They include the studies on the contribution of festivals to the welfare of local society through new job opportunities and the studies on festivals' provision of local renewal and revival (Prentice, Andersen 2003; Smith, 2004; Di Giovine, 2009). Furthermore, there is a study that highlights inter-institutional cooperation for suc- 
cessful processes in festival organizations (Yaghmour, Scott, 2009) and there is another study that draws attention to the roles of festival organizers and directors in determining the relationships between festival and local society (Gursoy et al., 2004). Some studies have contributed to the formation of a rich literature. These studies include a study that determines various indicators which evaluate cultural tourism in order to determine the tourism potential of smaller cultural and heritage attractions for the sustainability of cultural tourism (McKercher, Ho, 2006); a study that investigates the associations between overall satisfaction of tourists and the characteristics of cultural festival (Esu, Arrey, 2009); a study that makes proposals for the functions of bullfighting festivals and for the preservation and sustainment of this tradition in Japan (Kuwahara et al., 2000); and a study that evaluates the appeal of Water Buffalo Festival in Vietnam in terms of tourism (Son, 2OO4).

The idea that tourism would help conserve cultural heritages by inscribing them into the economic market has been challenged by a number of authors, who denounced the damage wrought by the commercialization of indigenous cultural traditions that have been transformed into tourist attractions (Picard, 2008:I59). Truly, living local cultures are undergoing an unavoidable process of change under the influence of globalization today. The cultural and social impacts, which might occur via tourism, have many impacts ranging from positive to negative positive to negative. According to Özgüç, these impacts lead to changes in the structure, and values, of the society and in artistic, religious and traditional practices (Özgüç, 2003: I62). Traditional events of local societies are especially influenced by cultural commodification, one of the most frequently quoted side effects of tourism (Cohen, I988; Hughes-Freeland, I993; Medina, 2003; Williams, 2003; Timothy, Boyd 2003).

Therefore, owing to the critical characteristics of tourism-intended festivals, some studies propose a careful management of these festivals for sustainability by considering them with a holistic sustainable approach (Quinn, 2006; Timothy, Nyaupane, 2009). Sustainable tourism generally implies a balanced mix of sustaining local economies, local cultures and local environments with an acceptable and desirable level of impact (Mitchell, 2008: I59). When the most commonly adopted concept of "sustainability" is applied to tourism, it is understood as "the regulation of use of tourism resources without being consumed, contaminated or emptied and in a way that will enable coming tourist generations to use them as well". Since it is not possible to transport or reproduce traditional events with touristic appeal, sustainable approaches are of importance for carrying such cultural heritages to the future. The positive role to be played by tourism in the conservation of local cultures is now accepted by everyone. In the following years as well, "cultural difference" will continue to rank at the top of the basic motives of tourists. This is only connected with the sustainability of existing cultural characteristics as they are (Özgüç, 2003:I94).

So far, there have been a rather limited number of studies on camel wrestles in Turkey (Akar, I994; Erdem, I998; Çulha, 2008; Çalışkan, 2009; Özdemir, Çulha, 2009). Akar evaluates the sociocultural dimension of camel wrestles in nomadic Turcomans, whereas in his study, Erdem conveys the events around camel wrestles as a public entertainment, with a description-based narration. Çulha (2008), who considers the subject within the scope of cultural tourism, evaluates the role of camel wrestles as a supplementary touristic product in Izmir. Özdemir and Çulha (2009) have investigated the satisfaction levels of visitors of the camel wrestling festival in Selçuk in terms of some festival elements and services. On the other hand, Çalışkan (2009) deals with camel wrestles on the scale of Turkey and puts forward their distributional characteristics and their functional structure as cultural heritage events. 


\section{Opportunities and hazards offered by tourism at 'Camel Wrestling Festival in Selçuk'}

People visiting cultural and historical resources are among the largest, most pervasive, and fastest growing sectors of the tourism industry today. In fact, heritage tourism appears to be growing much faster than all other forms of tourism, and is thus viewed as an important potential tool for community economic development (UNWTO, 2005). Tourist destinations are developing and promoting the cultural heritage of the people as a means of attracting and enhancing visitor experience. This is also because cultural and heritage tourism is being used as a tool to boost the local economy and has the potential to aid in the seasonal and geographical spread of tourism (Long, Perduce 1990). Additionally, today festivals are providing essential opportunities to provide tourism with dynamism, to share a country's culture with the world and to conserve, revive and sustain cultural heritage. Thus, upon the realization of the positive impacts of festivals especially on tourism economy in Turkey, the policy of combining festivals and tourism began to become evident after the I980s. The Selçuk Festival was the first to take action in this process, thereby acquiring the advantage of being recognized in comparison to other settlements, where camel wrestling events were held.

As Smith and Forest quoted from Zeppel and Hall (I992: 69), festivals enhance the tourist appeal of a destination and add vitality to it (Smith, Forest, 2006). The Camel Wrestling Festival in Selçuk offers an important opportunity for its environment which includes various cultural heritage riches. In fact, the term "heritage tourism products" refers to institutions, lifestyle-heritage opportunities, artefacts, heritage sites and events. These heritage products can be linked (Christou, 2005:8). When considered from this perspective, the programs containing the cultural heritage appeals in the locality in combination within the scope of the festival will also help form a cultural winter destination. Thus, while off-season tourism in Selçuk is revived throughout the festival week, various expenditures by foreign visitors contribute significantly to local economy. It is known that an increase in the number of visitors to such festivals leads to an increase in the demand for souvenirs and shopping. For instance, the Lantern Festival in Vietnam was a good example of such an impact. The lanterns bought as souvenirs by tourists in time turned into important export products, and local developments were observed in other labor-intensive handmade productions (Di Giovine, 2009). A similar process in this example is observed in the vicinity of camel wrestling organizations. Truly, camel wrestles have played a significant role in the survival of the traditional handicrafts manufactured to date in this region. Camel wrestles attract producers or sellers of labor-intensive handmade souvenirs from an extensive environment. These sellers make a living by moving during the wrestling season according to the wrestling calendar. Their number reaches 500 people in Selçuk Festival, which is the greatest organization.

Elements that might threaten this process and the opportunities for Selçuk Festival with its traditional and cultural dimensions exist simultaneously. The primary hazard concerned is the festival's loss of the authentic value of its material and moral elements. Controlling this process with sustainable approaches will doubtlessly protect it from hazards. However, while the camel wrestling festival in Selçuk is intended to be marketed touristically today, it is impossible to speak of any existing or future tourism policies. Nevertheless, what cultural heritage tourism aims should not be to earn great economic gains in the short term but to produce a stable tourism policy based on how to provide the sustainable use of resources in the long term (Emekli, 2006: 58).

According to Williams (2003:I6I), tourism may have negative impacts on material artistic elements: "the successful marketing of traditional objects as tourist souvenirs will alter 
their meanings or values, and where tourism markets develop, a tendency to increased dependence upon mass forms of production will marginalize the true craft worker." Hence, handicrafts begin to be commercialized with tourism. Upon the enlargement of the market, a handicraft transforms into mechanical art. Furthermore, bad copies for mass markets gradually occur (Özgüç, 2003:I62). Thus, the observation of cheap and bad copies from other countries among the souvenirs for foreign tourists, in this sense, indicates a danger. Yet, besides contributing to the local economy, the trade of touristic souvenirs is supportive of the sustainment of handmade productions of almost-lost traditional craftsmanship.

The transformation of a tourist event into a commercial one can be viewed as one of the negative impacts of tourism on traditional events. For instance, "devil dance" of Sri Lankan people and "firewalking" ceremonies of Tahitian and Fijian people used to be applied because of traditions; however, they have transformed into demonstrations in return for money for tourists, which makes the meaning of the events undergo a fundamental change (Özgüç, 2003:I62). In the process of commoditization, the spiritual meanings or customary values behind traditional celebrations, music, dances, and handicrafts are often lost as these cultural elements begin to be mass produced for tourist consumption. Traditional art forms are altered to meet the needs of tourists, and they too lose their value and become mass produced, meaningless, and inauthentic tourist kitsch (Timothy, Nyaupane, 2009:62).

Today wrestling organizations are based largely on "volunteerism". People working during the event (such as the jury and people working in the field) are those who are accepted in the surroundings of camel wrestles and who have no financial expectations. Nevertheless, with the acceleration of the commercialization process by the increasing touristic demands for the event, the metropolitan culture might dominate festivals soon. Particularly recently, it has been observed that those bourgeois wealthy people whose geographical origin and residence are located outside this field of culture have taken up a new hobby by purchasing expensive wrestling camels.

\section{Study Area}

With a population of 34,459 (TurkStat, 2008), Selçuk is a tourist town in the west of Turkey, 76 kilometers south of Izmir. Selçuk is located at coordinates $37^{\circ} 5 \mathrm{I}^{\prime}-38^{\circ}$ oI' N and $27^{\circ}$ I3' - $27^{\circ} 3 \mathrm{O}^{\prime} \mathrm{E}$. Selçuk, which has hosted various civilizations on the coast of the Aegean Sea, is a tourism center that is known worldwide with its historical, cultural, religious and natural touristic appeals. Ruins of the ancient city of Ephesus and the House of the Virgin Mary, which is regarded as a Pilgrimage center by the Vatican, attract tourists, who are curious about history, and candidate pilgrims. Other tourist draws include the Pamucak coast, one of the brilliant spaces of sea tourism; the Ephesus Museum, one of the most important local museums of Turkey; İsabey Mosque, dated to I375; the church wherein the tomb of St. John, the writer of Bible, located; Seljuk Castle, dating from Byzantine Period; Belevi (Bonita) mausoleum, dated to the Early Hellenistic Period; Şirince Village with its houses with their preserved historical architecture; the Byzantine aqueducts, still in good condition; and the Steam Locomotive Museum (Figure I). 


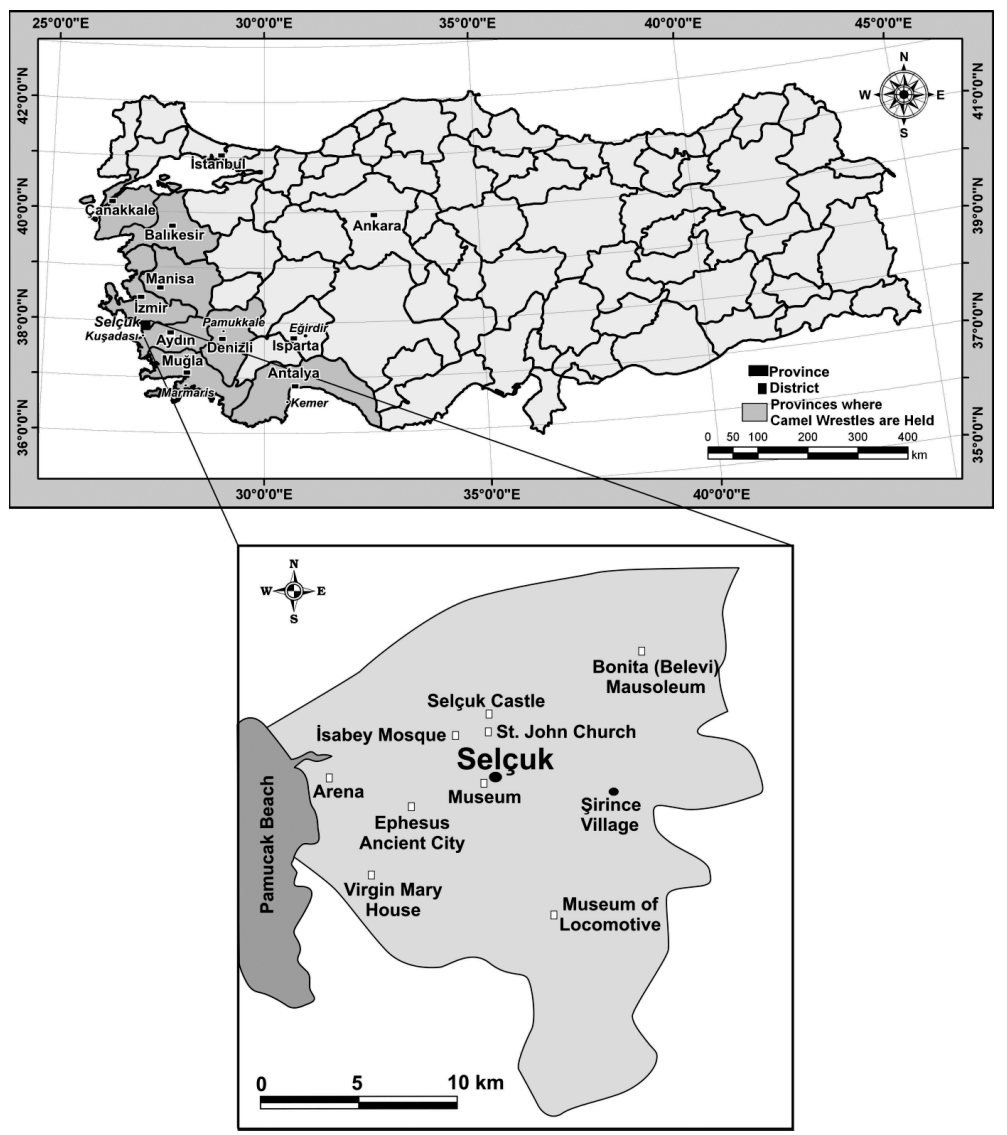

Figure 1. Map showing the location of Selçuk.

\section{Material and Method}

The basic research material consists of data provided by survey application, observations and interviews during fieldwork. The camel wrestling festival in Selçuk has been observed for the last three years and some 56 foreign visitors, who participated in the festival event as spectators in 2008-2009 season, were surveyed. Surveys were prepared in English and German. Random sampling and face to face interviewing techniques were used. There is no official figure with respect to the number of foreign visitors who participated in the organization. Depending on the observations in the study area, it might be estimated that this figure ranges from $4 \mathrm{OO}$ to 500. Since the survey questions were intended to investigate the camel wrestling experience of foreign visitors, the surveys had to be performed during the wrestles and around the arena. Due to this limitation, the surveys were performed by means of a group of pollsters in order to apply the highest number of surveys during the day. The surveys were applied under the supervision of the researcher by eight students at the Department of Geography, who had been provided with preliminary training about the survey technique before the activity. Before the application, the surrounding of the arena was divided into four sections. Surveys were applied to those who were voluntary among the foreign visitors encountered when two pollsters took a walk in each section. Careful attention was paid to the fact that the number of surveys applied 
to visitors, who were in groups, would not exceed $20 \%$ of the number of people in the group. On the other hand, no limitations were brought about in terms of age.

The survey form consisted mainly of two parts. Part I intended to determine the socioeconomic characteristics of individuals, whereas Part II consisted of questions to find the satisfaction of visitors with the medium, where the camel wrestle was held, as well as those aspects of the festival which were found attractive by visitors. The expressions specified in relation to the festival were presented in some questions of the survey, and the responses were measured with five-point Likert scale, with 'I' being 'strongly disagree' and ' 5 ' 'strongly agree'. In the evaluation of the results obtained from the surveys, the reliability analysis of the questions in Likert scale form was performed. Furthermore, whether there was any difference in tourists' categorical characteristics and their perception of the medium was investigated using One-way ANOVA. In some questions, however, it was possible for the surveyed people to mark more than one alternative. In such questions, the total number of markings was higher than the total number of samples.

Moreover, a limited interview that was composed only of one question was made with some I45 local spectators and 53 camel owners during the festival. During this interview, the local spectators were asked to only state their views of the touristic value of the Camel Wrestling Festival in Selçuk, while the camel owners were asked to state the three most favorable organizations for international tourism. So, it was aimed to find the general view of the local society about the participation of foreign visitors and the place of Selçuk Festival among other camel wrestling organizations.

\section{Findings and Discussion}

Survey results show that the festival attracted tourists from various countries worldwide. The surveyed foreign visitors were citizens of I4 countries (Table I). They mostly came from the countries which represented western culture. English, Dutch and Americans constituted approximately half of the foreign visitors. No visitors from Arabian countries, where camel contests were popular, were encountered during observations in the previous years or during this survey.

Of all responding visitors, I9 were female (33.9\%) and 36 were male $(64.3 \%)$, whereas one person did not state his/her sexuality (I.8\%). Their mean age was found as 4I.7 years and their age ranged between I6-73 years old. 28.6\% of the visitors were in the age group of 26-35 years. It is observed that the festival mostly attracted those visitors who were in the middle age group while young and elderly populations were also interested in the wrestles (Table 2).

Table 1. Distribution of visitors according to the Countries from which they came

\begin{tabular}{|l|c|c|l|c|c|}
\hline Country & Frequency & Percentage & Country & Frequency & Percentage \\
\hline England & 9 & 16.0 & Czech Republic & 2 & 3.6 \\
\hline Netherlands & 9 & 16.0 & Greece & 1 & 1.8 \\
\hline U.S.A. & 9 & 16.0 & Scotland & 1 & 1.8 \\
\hline Australia & 5 & 8.9 & Canada & 1 & 1.8 \\
\hline South Korea & 6 & 10.7 & Singapore & 1 & 1.8 \\
\hline Germany & 5 & 8.9 & Ireland & 1 & 1.8 \\
\hline Austria & 3 & 5.4 & Not Stated & 1 & 1.8 \\
\hline France & 2 & 3.6 & & & \\
\hline
\end{tabular}


Table 2. Age groups and gender of visitors

\begin{tabular}{|c|r|r|r|r|}
\hline \multirow{2}{*}{ Age Interval } & \multicolumn{3}{|c|}{ Gender } & \multirow{2}{*}{$\begin{array}{c}\text { Total Frequency- } \\
\text { Percentage }\end{array}$} \\
\cline { 2 - 5 } Younger than 18 & Female & Male & Not Stated & $1(1.8)$ \\
\hline $19-25$ & -- & 1 & -- & $7(12.5)$ \\
\hline $26-35$ & 4 & 3 & -- & -- \\
\hline $36-45$ & 6 & 10 & -- & $16(28.6)$ \\
\hline $46-55$ & 3 & 5 & 1 & $8(14.3)$ \\
\hline $56-65$ & 4 & 8 & -- & $13(23.2)$ \\
\hline $66+$ & 1 & 8 & -- & $9(16.1)$ \\
\hline Total & 1 & 1 & 1 & $2(3.6)$ \\
\hline
\end{tabular}

The profession and the educational status of foreign visitors demonstrate that they generally have a high socioeconomic level. Camel wrestles attract visitors from a broad variety of professional backgrounds ranging from diplomats (2 people) to the unemployed (I person). Due to the diversity of responses regarding professions in the survey, these professions were categorized. Classification of the groups in the workforce was based on the titles of major groups in 'International Standard Classification of Occupations 2008 (ISCO-O8)' (Table 3). Accordingly, 'Professional' group ranked the first. II people in this group were teachers. Approximately three-fourths of foreign visitors had a college/university degree (Table 4).

Table 3. Profession of visitors

\begin{tabular}{|l|r|r|}
\hline Profession & Frequency & Percentage \\
\hline Professional & 20 & 35.7 \\
\hline Student & 9 & 16.0 \\
\hline Service and sales workers & 5 & 8.9 \\
\hline Technicians and associate professionals & 3 & 5.4 \\
\hline Managers/administrative & 3 & 5.4 \\
\hline Craft and related trades works & 2 & 3.6 \\
\hline Armed forces & 2 & 3.6 \\
\hline Unemployed & 1 & 1.8 \\
\hline Retired & 5 & 8.9 \\
\hline Not Stated & 6 & 10.7 \\
\hline Total & 56 & 100.0 \\
\hline
\end{tabular}

Table 4. Educational status of visitors

\begin{tabular}{|l|r|r|}
\hline Educational Status & Frequency & \multicolumn{1}{|c|}{ Percentage } \\
\hline Elementary School & 1 & 1.8 \\
\hline High School & 10 & 17.8 \\
\hline College/University/Military College & 41 & 73.2 \\
\hline Vocational/Technical/Trade School & 2 & 3.6 \\
\hline Other & 1 & 1.8 \\
\hline Not Stated & 1 & 1.8 \\
\hline Total & 56 & 100.0 \\
\hline
\end{tabular}


The experience of visitors regarding Turkey was not new. As opposed to the 4I people (73.2\%), who had been to Turkey before, this was the first visit for I5 people (26.8\%). 9 visitors (I6.I\%), who had watched a camel wrestle before, indicate the recurrent feature of this experience. 42 visitors (75\%) had a camel wrestling experience for the first time. The visitors had quite various sources of information on the wrestles. When they were asked from which source they had learned that camel wrestles were held in Turkey, the response "friends" ranked the first. Totally 75 markings were made in this question, wherein more than one marking was possible. The absence of any expressions of "news in the media" among the responses highlights the lack of promotion of the event (Table 5).

Visitors participated in the festival primarily by themselves. The number of incomers with a group of tourists was rather limited (Table 6). In terms of their special interest in learning about the local culture in the place concerned, the visitors are distinguished from the organized mass tourist type. This characteristic is generally observed in festival visitors. Thus, as Smith and Forest quoted from Zeppel and Hall (I992: 69), "visitors primarily participate in festivals because of a special interest in the product, event, heritage or tradition being celebrated'. As a matter of fact, when visitors were asked "Why did you want to watch camel wrestles?", the three most marked responses were associated with "curiosity", "culture" and "an authentic experience", respectively. "Being interested in animal matches" was the least marked alternative. When a general evaluation is made by gender despite the insufficient number of samples, the rate of those who were interested in animal match is understood to be higher in the female group than in the male group. In the group of male visitors, "curiosity" and "authentic experience" were the most marked reasons for visit, whereas "learning about the culture" ranked the first in the group of female visitors (Table 7).

Approximately two-thirds of foreign visitors stayed in settlements other than Selçuk and participated to the festival with daily visits. Those who stayed in Selçuk constituted approx-

Table 5. Sources through which Visitors Learned the Existence of "Camel Wrestling Festival"

\begin{tabular}{|l|r|}
\hline Source of Information & Frequency \\
\hline Friends & $28(37.3 \%)$ \\
\hline Travel books & $17(22.7 \%)$ \\
\hline Tour guide & $10(13.3 \%)$ \\
\hline Internet & $9(12 \%)$ \\
\hline Touristic brochures & $5(6.7 \%)$ \\
\hline Tourism agency & $5(6.7 \%)$ \\
\hline Hotel & $1(1.3 \%)$ \\
\hline Total markings & 75 \\
\hline
\end{tabular}

Table 6. Mode of Participation of visitors in the Festival

\begin{tabular}{|l|r|r|}
\hline & Frequency & \multicolumn{1}{|c|}{ Percentage } \\
\hline By myself & 20 & 35.7 \\
\hline With my friends & 16 & 28.6 \\
\hline With my family & 12 & 21.4 \\
\hline With a group of tourists & 2 & 3.6 \\
\hline Other & 1 & 1.8 \\
\hline Not Stated & 5 & 8.9 \\
\hline Total & 56 & 100.0 \\
\hline
\end{tabular}


Table 7. Reasons for participation of visitors in the Festival

\begin{tabular}{|c|c|c|c|c|}
\hline & & Gender & & Total \\
\hline & Female & Male & Not Stated & \\
\hline Number of Respondents & 18 & 34 & 1 & 53 \\
\hline Because of curiosity & 9 & 19 & 1 & 29 \\
\hline Because I am interested in animal matches & 2 & 3 & - & 5 \\
\hline Because it is an authentic experience & 8 & 19 & 1 & 28 \\
\hline $\begin{array}{l}\text { In order to learn about the characteristics of } \\
\text { local culture }\end{array}$ & 11 & 15 & - & 26 \\
\hline $\begin{array}{l}\text { In order to spend time having fun with my } \\
\text { family/my friends/the group }\end{array}$ & 7 & 10 & - & 17 \\
\hline In order to take photographs & 10 & 13 & - & 23 \\
\hline Total markings & 47 & 79 & 2 & 128 \\
\hline
\end{tabular}

imately one-third of the total number of visitors. The visitors, who stayed outside Selçuk, came to the festival from 8 different settlements (İzmir, Marmaris, Kuşadası, İstanbul, Kemer, Eğirdir, Ankara and Pamukkale) (Figure I).

It is also possible to find out a connection between the festival and maritime tourism. IO visitors (I8\%) in the festival arrived in Turkey by yacht (The visitors stayed in Kemer, Kuşadası and Marmaris marinas and arrived in Selçuk for the Festival). Indicating the connection between Yacht Tourism and Cultural Tourism, this example is also a proof of the touristic appeal of Selçuk Festival. The nationalities of visitors and the locations of their marinas are tabulated below.

The high level of satisfaction is reflected by the quite high rate (92.8\%) of those who said they would recommend the camel wrestling experience to the people around them when they returned to their country. As a matter of fact, the number of visitors, who indicated that they would found the Festival atmosphere boring or disturbing, was only I (I.8\%). Nevertheless, three-fourths of the visitors considered the festival amusing and found the organization successful. The obtained results generally display a distribution that reflects visitor satisfaction (Table 8). Furthermore, apart from the protocol tribune with limited number of seats around the arena which foreign visitors do not prefer - there are no places arranged for sitting. The visitors were observed to have had problems of sitting; however, they did not seem to be complainant about this situation. Doubtlessly, foreign visitors' acceptance of this situation as a part of authenticity can account for their ignorance of comfort-related problems as festival spectators.

In this section of the survey, positive judgments were presented about the touristic appeal and potential of the event, and it was found out that the visitors largely agreed with these statements. The expression "the atmosphere has great richness in cultural sense" was highly (92.8\%) approved by the visitors. The rate of those who agreed with the statement "Camel wrestles are extraordinary and unique events" was likewise high (9I.I\%). There were a total of 4 people (7.2\%), who responded to the expression "Camel Wrestles are events that have a touristic value worldwide" with "strongly disagree" and "disagree", and there were Io people (I7.9\%) who stated to be neutral to the expression. In addition, 32.I\% stated to have agreed on the expression while $39.3 \%$ responded with "strongly agree". The results show that the "cultural richness" and "extraordinary" characteristics of the festival are the bases for touristic appeal for foreign visitors (Table 9).

Apart from foreign visitors, some I45 local spectators at the Festival were asked "In your opinion, do the camel wrestles in Selçuk have any touristic value worldwide?". I22 peo- 
Table 8. Evaluations of tourists concerning their satisfaction with the festival

\begin{tabular}{|c|c|c|c|c|c|c|c|}
\hline & & $\begin{array}{l}\text { Strongly } \\
\text { Disagree }\end{array}$ & Disagree & Neutral & Agree & $\begin{array}{l}\text { Strongly } \\
\text { Agree }\end{array}$ & $\begin{array}{l}\text { Total number } \\
\text { of responses- } \\
\text { percentage }\end{array}$ \\
\hline \multirow{2}{*}{ The atmosphere is amusing. } & Frequency & 1 & -- & 9 & 22 & 20 & 52 \\
\hline & Percentage & 1.8 & -- & 16.1 & 39.3 & 35.7 & 92.9 \\
\hline \multirow{2}{*}{$\begin{array}{l}\text { The atmosphere is boring / } \\
\text { disturbing. }\end{array}$} & Frequency & 41 & 12 & -- & -. & 1 & 54 \\
\hline & Percentage & 73.2 & 21.4 & -- & -. & 1.8 & 96.4 \\
\hline \multirow{2}{*}{$\begin{array}{l}\text { The needs of spectators } \\
\text { have been considered in the } \\
\text { organization. }\end{array}$} & Frequency & 1 & -. & 17 & 20 & 15 & 53 \\
\hline & Percentage & 1.8 & -- & 30.4 & 35.7 & 26.8 & 94.6 \\
\hline \multirow{2}{*}{$\begin{array}{l}\text { The seats are moderately } \\
\text { comfortable. }\end{array}$} & Frequency & 10 & 8 & 15 & 9 & 4 & 46 \\
\hline & Percentage & 17.9 & $14 \cdot 3$ & 26.8 & 16.1 & 7.1 & 82.1 \\
\hline \multirow{2}{*}{$\begin{array}{l}\text { The organization is generally } \\
\text { successful. }\end{array}$} & Frequency & 1 & -- & 9 & 22 & 20 & 52 \\
\hline & Percentage & 1.8 & -- & 16.1 & 39.3 & 35.7 & 92.9 \\
\hline \multirow{2}{*}{$\begin{array}{l}\text { When I return to my country, } \\
\text { I will recommend the people } \\
\text { around me to definitely have } \\
\text { this experience. }\end{array}$} & Frequency & 3 & -- & -- & 13 & 39 & 55 \\
\hline & Percentage & 5.4 & -- & -- & 23.2 & 69.6 & 98.2 \\
\hline
\end{tabular}

ple (84.I\%) responded to this question with "yes", whereas Io people (6.9\%) responded with "no" and I3 people (9.0\%) responded with "partially". Accordingly, the fact that local spectators generally considered the camel wrestling event an international touristic appeal also indirectly reflects their desire to share this value with foreign visitors.

In the statistical analysis of the survey questions and of some results, first of all, the reliability analysis of the part including the questions that had been prepared on Likert scale was performed and the scale concerned was found moderately reliable. The Cronbach's Alpha statistics calculated for reliability was found as 0.66I, whereas the average of all questions was found as 3.88. Depending on this, it might be expressed that the expressions in the scale generally corresponded to "4-I agree". On the other hand, minimum average in the descriptive statistics of the questions in the scale was obtained in the expression "The atmosphere is boring / disturbing". Originally, this question is inversely coded and indicates that the medium was not found boring by visitors. The highest average was obtained in the expression "The atmosphere has great richness in cultural sense" (4.78). This result shows that cultural attractiveness has an essential role in the perception of the event by tourists. In addition, when corrected item-total correlation was considered, it was found that no negative correla-

Table 9. Evaluations of foreign visitors regarding the appeal of the festival

\begin{tabular}{|l|l|r|r|r|r|r|r|}
\hline & & $\begin{array}{l}\text { Strongly } \\
\text { Disagree }\end{array}$ & Disagree & Neutral & Agree & $\begin{array}{c}\text { Strongly } \\
\text { Agree }\end{array}$ & $\begin{array}{l}\text { Total number } \\
\text { of responses } \\
\text {-percentage }\end{array}$ \\
\hline \multirow{2}{*}{$\begin{array}{l}\text { "Camel Wrestles" are events } \\
\text { that have a touristic value } \\
\text { worldwide. }\end{array}$} & Frequency & 3 & 1 & 10 & 18 & 22 & 54 \\
\cline { 2 - 8 } $\begin{array}{l}\text { "Camel Wrestles" are } \\
\text { extraordinary and unique } \\
\text { events. }\end{array}$ & Percentage & 5.4 & 1.8 & 17.9 & 32.1 & 39.3 & 96.4 \\
\cline { 2 - 8 } $\begin{array}{l}\text { The atmosphere has great } \\
\text { richness in cultural sense. }\end{array}$ & Percentage & -- & 1.8 & 5.4 & 23.2 & 67.9 & 55 \\
\cline { 2 - 8 } & Prequency & -- & -- & 3 & 6 & 46 & 98.2 \\
\hline
\end{tabular}


Table 10. Results for the analysis of questions prepared in Five-Point Likert Scale form

\begin{tabular}{|l|r|r|r|r|}
\hline & Mean & Std. Deviation & $\begin{array}{c}\text { Corrected Item- } \\
\text { Total Correlation }\end{array}$ & $\begin{array}{c}\text { Cronbach's Alpha } \\
\text { if Item Deleted }\end{array}$ \\
\hline The atmosphere is amusing. & 4.59 & .547 & .180 & .661 \\
\hline The atmosphere is boring / disturbing. & 1.34 & .728 & .658 \\
\hline $\begin{array}{l}\text { The needs of spectators have been considered in } \\
\text { the organization. }\end{array}$ & 3.80 & .901 & .315 & .641 \\
\hline The seats are moderately comfortable. & 2.78 & 1.215 & .483 & .437 \\
\hline The organization is generally successful. & 4.20 & .749 & .598 \\
\hline $\begin{array}{l}\text { When I return to my country, I will recommend } \\
\text { the people around me to definitely have this } \\
\text { experience. }\end{array}$ & 4.63 & .733 & .613 \\
\hline $\begin{array}{l}\text { "Camel Wrestles" are events that have a touristic } \\
\text { value worldwide. }\end{array}$ & 4.15 & .963 & .519 & .571 \\
\hline $\begin{array}{l}\text { "Camel Wrestles" are extraordinary and unique } \\
\text { events. }\end{array}$ & 4.68 & .567 & .594 & .613 \\
\hline $\begin{array}{l}\text { The atmosphere has great richness in cultural } \\
\text { sense. }\end{array}$ & 4.78 & .571 & .645 \\
\hline
\end{tabular}

tion was present. Therefore, no question to disturb the scale was found. Moreover, no question to significantly increase the reliability of the scale provided that it was deleted was found among the questions, either (Table IO).

It was investigated whether each question in the scale was perceived by tourists in such a way that it would yield different results, and whether the averages of the questions were equal was tested. In conclusion, averages of the questions were found to be different from each other [Hotelling's T-Squared=7I7.746; F= 74.0I8; P= O.OOOI].

Whether there was any difference between tourists' perceptions of the medium according to their categorical characteristics was investigated by one-way ANOVA. Accordingly, no significant difference could be detected between education level and perceptions of the festival medium ( $>>0.05)$. This analysis was made to cover the perceptions by graduates of High School, College/University/Military College and Vocational/Technical/Trade School only. Those categories which were answered by one person only were excluded from the analysis, for it was impossible to make a multiple comparison.

The perception of finding the organization successful by foreign visitors at the age interval of 26-35 years is positive at a higher level than other age groups. Whether there was any difference between the age categories of foreign visitors and their evaluations of the medium was investigated with One-way ANOVA. Depending on this, a significant correlation was found between the perception of finding the organization successful and the perception of finding the seats comfortable. The Bonferroni Post Hoc Test was referred to determine between which groups this difference was present. Accordingly, it was found that there was a significant difference between age groups of 26-35 years and 36-45 years in terms of tourists' perception of the success of the organization $(\mathrm{P}=0.036)$. Depending on this, it was determined that the perception of the organization as successful by the tourists at the age interval of 26-35 years was higher. One of the important factors that are influential on the comfort of spectators in the organization in fact is the absence of regular and convenient seats. However, in general, young spectators continuously move around the arena during the event and do not sit so much. Thus, they are not interested so much in the comfort of seats. The requirement of sitting mostly increases among the visitors in the advanced age groups. 
Table 11. Elements that Foreign Visitors liked or were impressed with the most at the Festival

\begin{tabular}{|l|c|l|}
\hline Atmosphere & Frequency & Comments \\
\hline Camels & 11 & $\begin{array}{l}\text { Local atmosphere, lively atmosphere, decoration and atmosphere, the } \\
\text { festival atmosphere }\end{array}$ \\
\hline People & 9 & $\begin{array}{l}\text { Camel's face, handsome camels, splendid camels, watching camels, color of } \\
\text { camels, camel's dressing, their size and how they wrestle, seeing camels in } \\
\text { street. }\end{array}$ \\
\hline Culture & 8 & $\begin{array}{l}\text { The people, people and crowd, many people, a lot of people, } \\
\text { experiences- diversity }\end{array}$ \\
\hline Tradition & 5 & \begin{tabular}{l} 
Tradition, traditional and authentic \\
\hline Other
\end{tabular} \\
\hline
\end{tabular}

As a matter of fact, as to the comfort of seats, a difference was found between the evaluations by those at the age groups of 36-45 years and 46-55 years ( $\mathrm{P}=\mathrm{0.027}$ ). Accordingly, the evaluations by tourists at the age interval of 36-45 years were found to be more positive than those at the age group of 46-55 years (mean= 3.78 at the age group of $36-45$ years, mean=I.83 at the age group of 46-55 years).

Furthermore, there were also some open-ended questions in the survey. To the open-ended question "as a spectator, what have you liked most/what has impressed you in camel wrestles?", 45 people responded with various answers. The most frequent responses included "atmosphere", "camels", "people", "culture" and "tradition". The obtained results demonstrate that various elements of the folk culture constitute an essential appeal for tourists (Table II).

Despite all these things, a cultural tourism attraction in itself does not make a tourism product. For that the attraction needs to be embedded in a whole range of services and facilities (Munsters and Klumbis, 2005). It is understood that some services offered to spectators during the festival event concerned were generally inadequate. While responding to the survey question "What are your suggestions for the betterment of this organization in touristic sense?", 30 people in total made various suggestions, among which the inadequacy of promotion and announcement of the festival ranked the first (23.2\%) (Table I2). In relation to this, it was suggested that tourist information bureaus be informed and websites be prepared in foreign languages for camel wrestles. As it is known, advances in information and communication technology (ICT) and the recent evolution of the Internet have been instrumental in transforming the production, interpretation, exchange, marketing and consumption of cultural services as well as in managing visitors' experiences and behavior (Sigala, 2005:I68). The establishment of a virtual cultural museum regarding camel wrestles might be beneficial both in the promotion of this culture to the world and for pre-event notification.

Table 12. Primary problems in festival organization according to visitors

\begin{tabular}{|l|r|}
\hline Problems & Frequency \\
\hline Inadequacy of promotion and announcements & 13 \\
\hline Openness of the event to foreign tourists & 6 \\
\hline Lack of explanations during camel wrestles & 5 \\
\hline Inadequacy of seats & 2 \\
\hline Absence of road signs from Selçuk to Pamucak & 30 \\
\hline Total & 8 \\
\hline
\end{tabular}


Since foreign visitors to the festival do not know the rules of wrestles and are unable to comprehend the meaning of the rituals, they generally have poor interaction with the event. Because live narrations of wrestles are performed in Turkish only, foreign visitors are mostly observers of the festival atmosphere. The enthusiasm and excitement of local spectators during camel wrestles are related to the fact that the wrestling camels belong to the people or settlements they are acquainted with. Hence, local spectators actively participate in the event. The impact of this excitement and the interesting universal names (such as Obama, Florida and Tsunami) of some camels enable foreign visitors, who would rather be observers, to interact with, and enjoy, wrestles. The problems foreign visitors stated regarding the festival displayed some contradictory cases, too. For instance, 23.2\% of the visitors found the promotion and announcement of the festival to the foreigners insufficient and suggested further promotion. Nevertheless, I4.3\% of the visitors considered it a problem that the festival was open to foreigners. Visitors find the cultural atmosphere, which results from the simple organization of the festival completely under the control of local society today, considerably valuable because of its naturalness. However, upon an increase in the interests of foreign visitors in the future, the organization and services might professionalize and enhance commercial expectations. As a matter of fact, some of the tourists expressed their concern that the transformation of the festival into a perfect organization in the future would inflict damage to this natural cultural atmosphere. It is quite significant that some foreign visitors made sincere suggestions that would exclude them from the event because they thought that their participation might inflict damage to the sustainability of this traditional event. It is clear that the suggestions concerned were made in order to protect the natural cultural fabric of the wrestling event from being ruined or to protect the event from being commercialized. Of 8 people, who suggested closing the event to foreign visits, 6 expressed their opinions in writing as well:

- "Don’t tell anyone. It's better to keep it a secret from foreigners."

- "Do not turn this into a touristic event, it will ruin the fun. Foreigners like me wouldn't come to it."

- "Leave it to suit the local people only not tourists."

- "Keep it traditional and local."

- "It should not appeal to tourists. Tourists would ruin it."

- "Don't ruin it by inviting foreign tourists. What makes it interesting and authentic is that it is not commercial."

The survey results indicate that the visitors at the festival were primarily male and from young- and middle-age groups. The visitors had a high education level, had special interest in culture, and differed from the type of organized mass tourist by participating in this touristic experience alone or with a group of friends. The fact that the responses included no expressions that judged the festival values and the fact that they did not prefer to speak of any comfort-related shortcomings reflect the visitors' style of being responsible tourists who primarily attached importance to authentic atmosphere. These results support previous judgments which accepted that tourist visitors at the festival primarily had the characteristics of attaching importance to cultural experience (Smith, Forest, 2006; Zeppel, Hall, I992). It was found that tourists had a very high level of satisfaction with the festival. However, there was no detectable correlation between demographics and general satisfaction. The fact that one-sixth of the visitors repeated their camel wrestling experience and that they would largely recommend the festival to the people around them are associated with their high levels of satisfaction. There is a significant difference in terms of the participants in the event and the experience of visiting Turkey. The rate of visitors in the event by those, 
who had visited Turkey before, was high. This result shows that they are acquainted with the Anatolian culture in more detail.

A sustainable approach should also include providing foreign visitors, who are components of the festival, with an authentic experience. With this purpose, it is important to target tourist satisfaction and determine their needs. Both service quality and visitor satisfaction are critical aspects of a heritage tourism service. Thus, if a heritage tourism provider ignores the psychological environment of the heritage tourism service experience, the result will be an incomplete understanding of the core tourism experience (Christou, 2005:I2). Such problems may have a negative impact on visitor's experience and inflict damage to the image of a destination and, in the long term, to tourism. Thus, some problems reflected on both observations and survey results at the festival in Selçuk indicated some problems regarding service facilities.

A previous study, which was based on a survey and dealt with the Camel Wrestling Festival in Selçuk in terms of tourism, found that the satisfaction levels of visitors were high (Özdemir, Çulha 2009). These results appear to be in concordance with those obtained in this study. Nevertheless, no distinctive information was available about the number or rate of domestic and foreign visitors surveyed in the study concerned. Thus, the results concerning the profile of foreign visitors at the festival were first put forward in detail in this study.

\section{Conclusion}

Among the traditional camel wrestles of Western Anatolia, the Selçuk camel wrestle was declared a festival as of the I980s and began to be promoted to the world with state support. Because of an increasing interest by foreign visitors during this process, this cultural value became a part of the cultural heritage tourism of Anatolia. Indeed, this new trend necessitates a search of some sustainable form, by taking into account the two-way opposite impact of tourism because the negative or positive impacts of tourism may easily become uncontrollable. Thus, there is a need for a sustainable tourism approach to protect this traditional event, which reflects local culture, protects against excessive commercialization and exploitation and ensures its preservation as it is.

It is sometimes difficult to detect the negative impacts to traditional festival events that are exposed to international tourism, for tourism generally progresses in the same way from a protective and supportive role to that of a destructive one. The Selçuk Festival is financially supported because of its contribution to the promotion of the country through tourism. Thus, this privilege is quite significant for the camel wrestling organizations which are concerned about the future under financial difficulties. This has led to a positive competition between the organizations in other tourist destinations which aimed to obtain support. When considered from this perspective, it is found that tourism plays an important role in the sustainment of camel wrestles. Undoubtedly, the avoidance of the destructive and uniforming impact of tourism depends on anticipating these hazards and ensuring that corrective measures are readied in a timely manner. The attitudes of organization committees in the processes of commercialization and loss of authentic meaning will be crucial. Hence, providing camel wrestles with a federative structure may suppress the commercial objectives of individuals and groups. Moreover, planning their organizations on a national scale under the roof of a federation will bring in other benefits, too. In this way, the areas, in which wrestles take place, may acquire some standards and better opportunities of use. In addition, a federation may justly apply the policy of distribution of the density of demands when necessary. 
Provided that there are great increases in touristic demand in the coming years, the most important problem for the festival might be that the social-perceptual capacity of local residents might be strained. When local residents of a place do not want tourists, it means that social-perceptual capacity has reached the maximum level. Damages inflicted to the local culture by foreign visitors or the difficulty of people in the local society in finding a place during local events are influential in reaching this level (Mowforth, Munt, 2003: 250). In this case, other touristic settlements, in which camel wrestles are held, might be put into use, and touristic demand might be redistributed. As a matter of fact, 53 wrestling-camel owners in Selçuk Festival were asked "what are the first three optimum wrestling organizations in Turkey for foreign visitors?”. A total of 22 organizations were suggested in the responses. Selçuk was the first preference of 40 camel owners while 48 people suggested Selçuk within the first three ranks. The responses show that Selçuk obtained a touristic brand in terms of camel wrestles. Other suggested organizations were Kuşadası (I5), Bodrum (I5), Yalıkavak (I4) and Germencik-Aydın (I3), respectively according to frequency of marking. These results give ideas about where to manipulate touristic demand in the future in case the bearing capacity of Selçuk is strained by foreign visitors.

In fact, the foreign visitors coming to the locality to participate in the event, in a sense, fulfill the touristic invitation of the festival. Sustainable approaches are required in order for visitors to live the festival experience significantly, and organizations are basically responsible for this process. With this purpose, first of all, it is necessary to deal comprehensively with service facilities within the scope of the event. Promotional and explanatory announcements in foreign languages during the wrestles will enhance the interaction of visitors with the event. Brochures to be prepared for foreign visitors may present explanatory information on the rules of a camel wrestle, music, ornamentation and rituals. The establishment of a museum to promote the camel wrestling culture in the locality will contribute to sharing this culture on national and international scales. Furthermore, in order to develop incomes of local people and tourist satisfaction together, accommodation opportunities might be created at the farms next to camel-dealing families in the locality, and operating guest facilities may be developed. A thematic hotel could be built and operated for the benefit of the camel wrestling organization.

\section{Acknowledgement}

I would like to individually thank my undergraduate students Belgizar Balcı, Ferit Arslan, Uğur Zerdali, Beste Kürekçioğlu, Şeyma Yılmaz, Damla Tunçel, Ufuk Manduz and Mustafa Balcığlu at the Department of Geography, who voluntarily worked to carry out the survey application. I would like to extend my thanks to my dear colleague Bahattin Hamarat for his contribution to the statistical analyses of the study.

\section{References}

Christou, E. (2005). Heritage and cultural tourism: a marketing focused approach. In M. Sigala and D. Leslie (Eds.), International Cultural Tourism: management, implications and cases. Elsevier.

Cohen, E. (I988). Authenticity and commoditization in tourism. Annals of Tourism Research, I5: $37 \mathrm{I}-86$. 
Çalışkan, V. (2009). Geography of a hidden cultural heritage: Camel wrestles in western Anatolia, The Journal of International Social Research, 2/8, I23-I37.

Çulha, O. (2008). Kültür turizmi kapsamında destekleyici turistik ürün olarak deve güreşi festivalleri üzerine bir alan çalışması, Journal of Yaşar University, 3(I2), I827-I852, (in Turkish).

Di Giovine, M. A. (2009). Revitalization and counter-revitalization: tourism, heritage, and the Lantern Festival as catalysts for regeneration in Hi An, Vi t- Nam, Journal of Policy Research in Tourism, Leisure and Events, I, 3, 208-23O.

Emekli, G. (2006). Coğrafya, Kültür ve Turizm: Kültürel Turizm (Geography, Culture and Tourism: Cultural Tourism), Ege Journal of Geography, I5:5I-59, (in Turkish).

Esu, B.B. and Arrey, V.M.E. (2OO9). Tourists' Satisfaction with Cultural Tourism Festival: a Case Study of Calabar Carnival Festival, Nigeria. International Journal of Business and Management, 4(3), II6-I25.

Gursoy, D., Kim, K., Uysal, M. (2004). Perceived impacts of festivals and special events by organizers: An extension and validation. Tourism Management, 25 (2), I7I-I8I.

Hughes-Freeland, F. (1993). Packaging dreams: Javanese perceptions of tourism and performance. Tourism in Southeast Asia, Routledge.

Ibrahimi, S.Y., (2007). "High Stakes in Afghan Camel wars", I8/04/2007, http://www. afghanistannewscenter.com/news/2007/april/apri92007.html

Ishii, H. (2006). Bullfighting: Tradition and Acculturation, International Journal of Sport and Health Science 4, Tokyo, Japan.

Khalaf, S. (2000). Poetics and politics of newly invented traditions in the Gulf: Camel Racing in the United Arab Emirates, Ethnology, Vol. 39. 243-26I.

Kuwahara, S., Ozaki, T. and Nishimura, A. (2007). Transperipheral Networks: Bullfighting and Cattle Culture in Japan's Outer Islands. Shima: The International Journal of Research into Island Cultures, I (2), I-I3.

Long, P. T. and Perduce, R.R. (I990). The economic impact of rural festivals and special events: assessing the spatial distribution of expenditure. Journal of Travel Research, 28(4):IO-I4.

McKercher, B. and Ho, P.S.Y. (2006). Assessing the tourism potential of smaller cultural and heritage attractions, Journal of Sustainable Tourism, I4 (5), 473 - 488.

Medina, L.K. (2003). Commoditizing culture: tourism and Maya identity. Annals of Tourism Research, 30: 353-68.

Mitchell, R.E. (2008). Community Perspectives in Sustainable Tourism: Lessons from Peru. In S.F. McCool, R.N. Moisey (Eds). Tourism, Recreation and Sustainability, CABI.

Mowforth, M., Munt, I. (2003). Tourism and Sustainability, Taylor \& Francis e-Library.

Munsters, W., Klumbis, D.F. (2005). Culture as a component of the hospitality product. In M. Sigala and D. Leslie (Eds), International Cultural Tourism: management, implications and cases. Elsevier.

Nawata, H. (2005). Historical socio-economic relationships between the Rashayda and the Beja in the eastern Sudan: the production of racing camels and trade networks across the Red Sea. Osaka National Museum of Ethnology, I87-2I3.

Ozdemir, G., Çulha, O. (2009). Satisfaction and Loyalty of Festival Visitors, Anatolia: An International Journal of Tourism and Hospitality Research 2O, 359-373.

Özgüç, N. (2003). Turizm Coğrafyası (Tourism Geography), Çantay Kitabevi, İstanbul (in Turkish). 
Picard, D., Robinson, M. (2006). Remaking worlds: festivals, tourism and change. In M. Robinson, A. Phipps (Eds). Festivals, Tourism and Social Change Remaking Worlds, Tourısm and Cultural Change Series: 8, Channel View Publications.

Picard, M. (2008). Balinese identity as tourist attraction from 'cultural tourism' (pariwisata budaya) to 'Bali erect' (ajeg Bali), Tourist Studies, 8, I55-I73.

Prentice, K. (1993). Tourism and Heritage Attractions. London: Routledge.

Prentice, R. and Andersen, U. (2003). Evoking Ireland: modeling tourist propensity. Annals of Tourism Research, 27 (2), 490-5I6.

Quinn, B. (2006). Problematising 'festival tourism': arts festivals and sustainable development in Ireland. Journal of Sustainable Tourism, I4 (3), 288 -306.

Raza, M.T., 2008, “camel wrestling owes it to "the king”, January I2, http://www.dawn. com/2008/OI/I2/nat27.htm

Robertson, R., Rogers, P., Leask, A. (2009). Progressing socio-cultural impact evaluation for festivals. Journal of Policy Research in Tourism, Leisure and Events, I:2,I56-I69.

Shubert, A. (2OOI). Death and Money in the Afternoon: A History of the Spanish Bullfight. Oxford University Press.

Sigala, M. (2005). New media and technologies: trends and management issues for cultural tourism, In M. Sigala and D. Leslie (Eds), International Cultural Tourism: management, implications and cases. Elsevier.

Smith, M. and Forest, K. (2006). Festivals, tourism and the complexities of performing culture remaking worlds: Festivals, tourism and change. In M. Robinson and A. Phipps (Eds). Festivals, Tourism and Social Change Remaking Worlds, Channel View Publications.

Son, B. H. (20O4). Tourism and the preservation of heritage sites in Vietnam: a case study of a water buffalo fighting festival and its tourist attraction, Social Sciences 6, 3I-44.

Williams, S. (2003). Tourism Geography, Contemporary Human Geography Series, Routledge.

Tighe, A. (I986). The arts/tourism partnership. Journal of Travel Research, 24(I): 2-5.

Timothy, D.J., Boyd, S.W. (2003). Heritage Tourism. Harlow: Prentice Hall.

Timothy, D.J., Boyd, S.W. (2006). Heritage tourism in the 2Ist century: valued traditions and new perspectives. Journal of Heritage Tourism, I(I): I-I6.

Timothy D. J., Nyaupane G. P. (2009). Heritage tourism and its impacts. Cultural Heritage and Tourism in the Developing World A regional perspective. In D.J. Timothy and G.P. Nyaupane (Eds.), Routledge.

TurkStat. (2008). (Turkish Statistical Institute), Population and Demography, http:// www.tuik.gov.tr

Türkoğlu, M. (I990). Türkiye'de Bir Madrid: Artvin (A Madrid in Turkey: Artvin), PTT Dergisi, 93:I6-I8, (in Turkish).

UNWTO (2005). Cultural Tourism and Poverty Alleviation: The Asia-Pacific Perspective.

Madrid: World Tourism Organization.

Yaghmour, S. and Scott, N. (2009). Inter-organizational collaboration characteristics and outcomes: a case study of the Jeddah Festival. Journal of Policy Research in Tourism, Leisure and Events.I:2, II5-I3O.

Zeppel, H. and Hall, C.M. (I992). Arts and heritage tourism. In B. Weiler, C.M. Hall (Eds.), Special Interest Tourism. London: Belhaven Press. 47-65. 